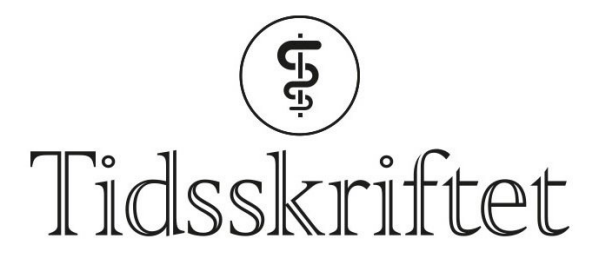

DEN NORSKE LEGEFORENING

\title{
Nye anbefalinger ved serumkonsentrasjonsmålinger av sentralstimulerende legemidler
}

DEBATT

\section{JOACHIM FROST}

E-post: joachim.frost@stolav.no

Joachim Frost er overlege ved Avdeling for klinisk farmakologi, St. Olavs hospital.

Forfatteren har fylt ut ICMJE-skjemaet og oppgir ingen interessekonflikter.

\section{JEAN-PAUL BERNARD}

Jean-Paul Bernard er overlege ved Senter for psykofarmakologi, Diakonhjemmet sykehus.

Forfatteren har fylt ut ICMJE-skjemaet og oppgir ingen interessekonflikter.

\section{ERIK SVEBERG DIETRICHS}

Erik Sveberg Dietrichs er overlege ved Klinisk farmakologi, Laboratoriemedisin, Universitetssykehuset Nord-Norge.

Forfatteren har fylt ut ICMJE-skjemaet og oppgir ingen interessekonflikter.

\section{KARI KJELDSTADLI}

Kari Kjeldstadli er overlege ved Seksjon for klinisk farmakologi, Avdeling for farmakologi, Oslo universitetssykehus.

Forfatteren har fylt ut ICMJE-skjemaet og oppgir ingen interessekonflikter.

\section{BETTINA RIEDEL}

Bettina Riedel er avdelingsoverlege for klinisk farmakologi ved Laboratorieklinikken, Haukeland universitetssjukehus.

Forfatteren har fylt ut ICMJE-skjemaet og oppgir ingen interessekonflikter.

\section{RAGNHILD BERGENE SKRÅSTAD}

Ragnhild Bergene Skråstad er lege i spesialisering ved Avdeling for klinisk farmakologi, St. Olavs hospital.

Forfatteren har fylt ut ICMJE-skjemaet og oppgir ingen interessekonflikter.

\section{MERETE VEVELSTAD}

Merete Vevelstad er overlege ved Avdeling for rettsmedisinske fag, Oslo universitetssykehus. Forfatteren har fylt ut ICMJE-skjemaet og oppgir ingen interessekonflikter. 
Sentralstimulerende legemidler brukes i økende grad innen behandling av ADHD/hyperkinetisk forstyrrelse i Norge. Måling av serumkonsentrasjonen kan være aktuelt for å evaluere terapieffekter, etterlevelse og eventuelt misbruk. Det er nå kommet nye nasjonale referanseområder for de hyppigst brukte ADHD-midlene.

Terapeutisk legemiddelmonitorering benyttes som beslutningsstøtte for dosering av en rekke legemidler. Ulike analyselaboratorier i Norge opererer tidvis med forskjellige referanseområder for legemidlers konsentrasjonsnivå. Innen gruppene sentralstimulerende legemidler/ADHD-midler har det vært store forskjeller i og uklart grunnlag for referanseområdene.

Norsk forening for klinisk farmakologi lanserte i februar 2015 Farmakologiportalen som en felles nasjonal nettportal for farmakologiske og toksikologiske analyser (1). Laboratoriene som er representert i portalen, bør bruke de samme referanseområdene. En slik harmonisering sikrer en mer entydig og faglig kvalitetssikret tilbakemelding til rekvirentene, uavhengig av hvor analysen er utført. Felles nasjonale referanseområder er så langt blitt etablert for antiepileptika, antikoagulantia, benzodiazepiner, z-hypnotika og opioider (2-4).

I 2017 opprettet Norsk forening for klinisk farmakologi en arbeidsgruppe som skulle utarbeide forslag til felles referanseområder for de hyppigst brukte sentralstimulerende legemidlene ved behandling av ADHD, det vil si metylfenidat, amfetamin og atomoksetin. Arbeidsgruppen har nå ferdigstilt sin sluttrapport.(5).

\section{Oppdaterte, felles referanseområder}

Rapporten baserer seg på en internasjonal konsensusartikkel om bruk av terapeutisk legemiddelmonitorering (6), farmakokinetiske data fra litteraturen og beregninger fra prøver til terapeutisk legemiddelmonitorering analysert ved de ulike analyselaboratoriene i Norge. Arbeidsgruppen har på denne bakgrunn foretatt en totalvurdering, hvor det er lagt mest vekt på data fra målinger i vår daglige rutine, både fordi dette best speiler den virkeligheten vi arbeider i (vår pasientpopulasjon, våre analysemetoder, våre behandlingstradisjoner), og fordi de andre datakildene ikke viser til noen sikker klinisk dokumentasjon for terapeutiske serumkonsentrasjoner av de aktuelle stoffene. En detaljert beskrivelse av arbeidsmetoden og resultatene finnes i sluttrapporten (5). Rapporten har vært på høring i det norske klinisk farmakologiske fagmiljøet og i de fagmedisinske foreningene for psykiatri, barne- og ungdomspsykiatri, barnesykdommer, nevrologi, rus- og avhengighetsmedisin og allmennmedisin, og er etter dette godkjent av styret i Norsk forening for klinisk farmakologi. De nye referanseområdene er dermed gjeldende, og oppføringene for de aktuelle substansene i Farmakologiportalen er oppdatert.

En oversikt over de nye referanseområdene er fremstilt i tabell 1.

\section{Tabell 1}

Nye nasjonale referanseområder for serumkonsentrasjoner av de hyppigst brukte sentralstimulerende legemidlene ved $\operatorname{ADHD}(5)$.

\begin{tabular}{|ccc|}
\hline Medikament & Nytt referanseomåde (nanomol/I) Anbefalt tid for blodprøvetaking \\
\hline Metylfenidat & $1000-4000^{1}$ & 4-8 timer etter siste inntak \\
\hline Amfetamin & $100-800^{2}$ & $4-8$ timer etter siste inntak \\
\hline Atomoksetin & $300-4000$ & $4-8$ timer etter siste inntak \\
\hline
\end{tabular}

${ }^{1}$ Gjelder metabolitten ritalinsyre

${ }^{2}$ Gjelder ved bruk av deksamfetamin/lisdeksamfetamin. Ikke definert for racemisk amfetamin 
Referanseområdene gjelder for blodprøver tatt 4-8 timer etter siste perorale inntak, for alle midler og formuleringer. Tidligere var anbefalt tid for prøvetaking uklart og ulikt definert ved de forskjellige utførende analyselaboratoriene. Arbeidsgruppen har begrunnet denne nye anbefalingen dels med behovet for en harmonisert og enhetlig praksis i seg selv. Arbeidsgruppen antar også at det beste samsvaret mellom serumkonsentrasjon og ønsket effekt ved ADHD vil sammenfalle med tiden rundt konsentrasjonsmaksimum etter peroralt inntak og de første timene etter dette. Tidsperioden 4-8 timer etter inntak omfattes også av tidsrommet for ønsket terapieffekt. Det er ikke funnet grunnlag for å anbefale differensierte referanseområder for voksne og barn.

Vi håper at de nye nasjonalt harmoniserte referanseområdene vil gi et bedre støtteverktøy til medikamentell behandling og oppfølging av pasienter med ADHD

Referanseområdene er definert på farmakokinetisk grunnlag og angir forventet konsentrasjonsområde ved bruk av vanlige terapeutiske doser av de ulike midlene. Sammenhengen mellom serumkonsentrasjon og effekt for disse midlene er ikke entydig eller godt klinisk dokumentert, og optimal serumkonsentrasjon vil variere mellom enkeltpasienter. Særlig for ritalinsyre, som er en inaktiv metabolitt av metylfenidat, er sammenhengen mellom målt konsentrasjon og klinisk effekt usikker. Analyseresultatet bør hovedsakelig brukes til å kontrollere etterlevelse av behandling. For alle midlene gjelder at klinisk vurdering alltid bør være avgjørende i bedømmelsen av hva som er optimal dose for den enkelte pasient og hvorvidt det er behov for doseendring. Vi håper imidlertid at de nye nasjonalt harmoniserte referanseområdene vil gi et klarere og bedre støtteverktøy til medikamentell behandling og oppfølging av pasienter med ADHD enn tidligere.

\section{LITTERATUR:}

1. Farmakologiportalen. Norsk portal for legemiddel- og rusmiddelanalyser. www.farmakologiportalen.no Lest 12.4.2019.

2. Reimers A, Berg JA, Burns ML et al. Felles referanseområder for antiepileptika. Tidsskr Nor Legeforen 2017; 137: 864-5. [PubMed][CrossRef]

3. Lundgaard H, Dyrkorn R, Stokes CL et al. Tryggere behandling med serumkonsentrasjonsmåling av de nye antikoagulasjonsmidlene? Tidsskr Nor Legeforen 2016; 136:1556-6o. [PubMed][CrossRef]

4. Helland A, Berg JA, Gustavsen I et al. Serumkonsentrasjonsmålinger av vanedannende legemidler. Tidsskr Nor Legeforen 2016; 136: 400-2. [PubMed][CrossRef]

5. Farmakologiportalen. Nasjonale referanseområder -

prosjektrapporter. http://www.farmakologiportalen.no/nasjonale_referanseomrader/ Lest 12.8.2019.

6. Hiemke C, Baumann P, Bergemann N et al. AGNP consensus guidelines for therapeutic drug monitoring in psychiatry: update 2017. Pharmacopsychiatry 2018; 51: 9-62. [PubMed][CrossRef]

Publisert: 23. september 2019. Tidsskr Nor Legeforen. DOI: 10.4045/tidsskr.19.0385

Mottatt 30.5.2019, godkjent 21.8.2019.

(C) Tidsskrift for Den norske legeforening 2020. Lastet ned fra tidsskriftet.no 